\title{
Sociological and Grounded, but Everyday?
}

\author{
Eleanor Knott \\ London School of Economics, UK \\ Email: e.k.knott@lse.ac.uk
}

Grounded Nationalisms: A Sociological Analysis, by Siniša Malešević, Cambridge University Press, 2019, \$89.99 (hardcover), ISBN 9781108425162 , \$29.99 (paperback), ISBN 9781108441247

Grounded Nationalisms, as its name suggests, provides a rich historical and sociological account concerning the paradoxical persistence of nationalism. What motivates Malešević to write this book is precisely such a paradox, presenting nationalism as an ideologically bereft, anomalous, and exceptional political and social force, and evidence that suggests the contrary. As Malešević argues, "rather than being a historical abnormality and a temporary irritation," nationalism has continued as "the dominant form of modern subjectivity" because it is a cross-cutting "social practice embedded in the everyday life of modern societies" (2019, 3-4). In other words, Malešević's rich historical and sociological perspective provides the evidentiary and analytical flesh to see nationalism as "a super-thick ideology, a meta-ideological doctrine, which penetrates daily interactions of human beings and as such also shapes how modern individuals see and act in their social world" (4).

This book returns and contributes significantly to one of the central cleavages of nationalism studies-namely, the debate between ethnosymbolists (like Smith and Hutchinson) and modernists (like Gellner and Breuilly) - by integrating newer scholarship from everyday nationalism perspectives with a historical perspective. Finally, Malešević provides convincing arguments to oppose debates of "new nationalism" emerging since Trump and Brexit. Rather, he illustrates from a grounded sociological and historical perspective that there is nothing new about nationalism as a dominant ideology and social force.

Indeed, this is the bigger question motivating Malešević's study: Why does nationalism remain the "most potent operative ideological discourse in the modern era" (8)? To do so, Malešević (8-14) introduces the concept of grounded nationalism to demonstrate (and establish a methodology to explore) nationalism as (1) "historically grounded," as strong and persistent over time; (2) "organisationally grounded," via social organizations and the nation-state; (3) "ideologically grounded," by establishing norms of "collective liberation and emancipation" whereby the nation-state is the "pinnacle of human progress"; and (4) "micro-interactionally grounded," following scholars of everyday nationalism who view nationalism "understandable and meaningful" via the "daily interactions of ordinary individuals.”

\section{Everyday Nationalism and Grounded Nationalism}

Everyday nationalism has been an emergent field and approach in nationalism studies, which argues that nationalism should be understood as functioning, and studied, through the meanings and practices of ordinary people that manifest the nation at the level of the everyday, rather than via top-down discourses, articulations, and practices of the state and elite (Fox and Miller-Idriss 2008;

\footnotetext{
(C) The Author(s), 2021. Published by Cambridge University Press on behalf of Association for the Study of Nationalities. This is an Open Access article, distributed under the terms of the Creative Commons Attribution licence (http://creativecommons.org/licenses/by/4.0/), which permits unrestricted re-use, distribution, and reproduction in any medium, provided the original work is properly cited.
} 
Brubaker et al. 2006; Goode and Stroup 2015; Knott 2016; Skey 2011; Antonsich 2016). What Malešević contributes to understandings of everyday nationalism is both a historical perspective and his constructivist lens. Such a constructivist lens emphasizes neither the structural dynamics of nationalism nor the agential components, as scholars of everyday nationalism do; rather, nationalism is a product of structure-agent interactions; "nationalism is generated in the structural sphere but its continuous existence is heavily dependent on the everyday micro-interactional grounding" (14). While a constructivist approach is implicit in everyday nationalism approaches prior to Malešević, the focus on structural factors and forces-namely, the organizational and ideological dynamics of the nation-state-has often been absent (Antonsich 2020, 1234). Indeed, Malešević's approach has guided others to take an everyday lens to integrate such a macro/structural and micro/ everyday and an interactional perspective (Erdal and Fangen 2021).

In many ways, Malešević is able to wrap approaches and theories of everyday nationalism, which previously have seemed offline to broader debates within nationalism studies over the origins of nations and nationalism, within an argument that everyday dynamics-via microinteractions and legitimization strategies - matter. But where does this leave the study of everyday nationalism?

As I argue elsewhere, approaches to everyday nationalism offer not only a theory of nationalism - for whom the nation matters (or does not) - but also imply a methodology of nationalism. To study nationalism, we must also study those who participate in nationalist projects and nationstates in everyday terms; we must study not only elites but ordinary people. What distinguishes the study of banal and everyday nationalism is precisely a more sociological and bottom-up engagement with the citizens that comprise nation-states. Such methods require a degree of presentism to gain the thickness of data that comes from immersion in a particular field site at a particular moment, in turn sacrificing historical breadth for sociological and contemporary depth.

What does a historically grounded approach to everyday nationalism look like? How do we, in reality, integrate everyday nationalism approaches within a historical and structural perspective? To do study the nation through the lens of the everyday and historical, would require and render (potentially) only oral histories conducted in the past, or concerning the past through the lens of the present, as a method with sufficient ethnographic depth to study nationalism through the lens of everyday meanings and practices.

This is not to suggest that Malešević doesn't drill into the levels of meanings and practices. He certainly does when exploring the transformation of Irish nationalism from something that was "insecure and weakly grounded in everyday life" in the 1940s and 1950s to something that "is well established and constantly reproduced in everyday practices" (150-151), from sport to culture, including the contemporary salience of traditional music and dancing. For example, he what shows how national festivals and memorials that might otherwise be viewed simply as religious and state practices, of St Patrick's day and the 1916 Easter Uprising, as not only nationalist and grounded practices but as practices infused with religiously and gender inclusive norms that "celebrate multiculturalism" (155). ${ }^{1}$ But such a drilling is also not mediated through the lens of how such meanings and practices are understood by those for whom they are meaningful and being practiced-namely, the participants of such movements and events.

My point is not to emphasize an unnecessary distinction or pick a fight with an epistemological and theoretical ally. Rather, my point is to demonstrate that there are differences between what a grounded and everyday approach to nationalism seek to explore, explain, and contribute knowledge about. Moreover, there are both practical and methodological challenges of integrating a historical and everyday approach to the study of nationalism. Hence, rather than intersect everyday nationalism and grounded historical study, a more feasible middle ground for scholars guided more by an ethnographic approach to everyday nationalism might be historical contextualization of everyday nationalist accounts and sociological framing of historical accounts (e.g., the actors and voices that are incorporated and a diversity of data sources, like oral histories or perhaps diaries or novels, where available). 


\section{Grounded Nationalism as a Challenge to New Nationalism}

Malešević mobilizes his understanding of nationalism, in particular, to critique notions of new nationalism that explain the seemingly increasing salience of nationalism and anti-immigration sentiments. Such perspectives view nationalism as an aberration and, as Malešević argues, are by their nature dehistorical by overemphasizing recent events, such as Trump and Brexit, rather than historically contextualize the ebb and flow over nationalism over the modern period. As Malešević argues, nationalism was not in decline before the term "new nationalism" was coined but "was and remains the dominant operative ideology of modernity" $(2019,241)$.

Indeed, Malešević goes further to argue, in relation to globalization and cosmopolitanism, that these modern social and political processes have not unmoored nationalism as the dominant norm. According to Malešević, the continued salience and proliferation of the state, ideologically and organizationally, has furthered the hegemony of nationalism where the permeation of the nationstate in daily practice remains central, especially when compared to the weakness of most nationstates in the 19th century and before.

This is where Malešević convincingly mobilizes the everyday approach to nationalism that, integrated within a grounded approach, demonstrates the need to study that which is "habitually reproduced, organisationally deep-rooted, ideologically well diffused, and also capable of penetrating successfully into the microcosm of daily routine." By doing so, Malešević argues, we can actually observe "how the strength of nationalism resides in its ground-ness, the well-entrenched and firmly embedded nationalisms are generally less visible to the naked eye"; where what we need to study are not the "noisy, barking nationalisms" that reach the headlines but the "tranquil, biting, nationalisms that really matter" (279).

If nationalism is neither new nor on the resurgence, as a scholar of citizenship my remaining question concerns the impact on citizenship. Indeed, literature on citizenship and nationalism can often talk past each other rather than engage with their commonalities concerning their objects of analysis. As Harpaz writes, "Citizenship is today the most important factor that determines a person's life chances-more than class, race or gender" $(2015,2086)$. Citizenship is a producer of global inequality (Shachar 2009) by the proliferation of citizenship-by-investment schemes that bifurcate wealthy mobile from impoverished, disempowered, and immobile individuals. Citizenship is also tied to nationalist projects via its proliferation by kin-states, such as Croatia, Hungary, Romania, and Austria, to co-ethnic kin; indeed, it is many of the same states that prevent facilitated naturalization from long-term immigrants and restrict refugees. Antiimmigration sentiment may not be caused by the resurgence of nationalism (because there might be no resurgence of nationalism in the first place). But with the continued dominance of the nation-state as the political container of societies, and nationalism as its dominant ideology, is nationalism-organizationally and via microinteractions-responsible for the continued hardening of citizenship? If so, how? In other words, how do nationalism and citizenship intersect to continue to perpetuate a model of citizenship that retains such salience and is highly consequential for life chances?

\section{Grounded Nationalism and the Nation-State}

Finally, one question I found myself asking is: Why is the nation-state so persistent as an organizing and legitimizing container? Malešević does offer convincing arguments for such developments, in particular by tracing the development of the nation-state and nationalism in Serbia, Bulgaria, and Ireland, among other cases. Indeed, Malešević convincingly argues that nation-states appear to draw on strategies used by imperial political forms as part of legitimizing projects.

But what was less clear is how the nature of the nation-state, and in particular its coercive and authoritarian power, affects nationalism at the organizational, ideological, and everyday level. Put simply, do democracies and authoritarian nation-states build and reproduce nations in the same 
way? Do citizens of democracies and authoritarian states experience the relationship between nationalism and the nation-state in the same or different ways?

While we might have a hunch that democracies and authoritarian regimes, as well as hybrid regimes, produce different forms of nationalisms, via different legitimation strategies, and are experienced by citizens in different ways, this is not something touched on by Malešević. It also reflects a cleavage in existing studies of everyday nationalism that occur either within democratic, hybrid, or authoritarian regimes, but rarely across such regime types. Indeed, the cases drawn on by Malešević do represent some of this democratic-authoritarian variation, in particular when viewed over time, but such a comparison is not made explicit (perhaps because Malešević is a sociologist rather than a political scientist). Such a comparison, over time within cases and between cases, could be a fruitful avenue for future researchers of nationalism, and grounded and everyday nationalism in particular.

\section{Note}

1 Albeit it might be that Catholic ethnic minorities could have an easier time integrating in such national performances than non-Catholic ethnic minorities.

\section{References}

Antonsich, Marco. 2016. “The ‘Everyday’ of Banal Nationalism: Ordinary People’s Views on Italy and Italian.” Political Geography 54:32-42.

Antonsich, Marco. 2020. “Everyday Nation in Times of Rising Nationalism.” Sociology 54 (6): 1230-1237.

Brubaker, Rogers, Margit Feischmidt, Jon Fox, and Liana Grancea. 2006. Nationalist Politics and Everyday Ethnicity in a Transylvanian Town. Princeton: Princeton University Press.

Erdal, Marta Bivand, and Katrine Fangen. 2021. "A State-Centred Conception of Nationhood? Norwegian Bureaucrats on the Nation." Ethnicities, April.

Fox, Jon E., and Cynthia Miller-Idriss. 2008. “Everyday Nationhood.” Ethnicities 8 (4): 536-563.

Goode, Paul J., and David R. Stroup. 2015. "Everyday Nationalism: Constructivism for the Masses.” Social Science Quarterly 96 (3): 717-739.

Harpaz, Yossi. 2015. “Ancestry into Opportunity: How Global Inequality Drives Demand for Long-Distance European Union Citizenship.” Journal of Ethnic and Migration Studies 41 (13): 2081-2104.

Knott, Eleanor. 2016. "Everyday Nationalism: A Review of the Literature." Studies on National Movements 3.

Malešević, Siniša. 2019. Grounded Nationalisms: A Sociological Analysis. Cambridge: Cambridge University Press.

Shachar, Ayelet. 2009. The Birthright Lottery: Citizenship and Global Inequality. Cambridge, MA: Harvard University Press.

Skey, Michael. 2011. National Belonging and Everyday Life: The Significance of Nationhood in an Uncertain World. New York: Palgrave Macmillan. 